\title{
POLA PEMBINAAN INTERNATIONAL JUNIOR SCIENCE OLYMPIAD (IJSO) IPA DI TINGKAT NASIONAL
}

\author{
Yunita \\ Fakultas Tarbiyah UIN Sunan Gunung Djati Bandung
}

\begin{abstract}
The aim of IJSO are : 1 ) Increasing students' interest toward science (physics, chemistry, and biology) and mathematics since at the junior level, 2) providing motivation for students to become more hardworking, 3) As a vehicle for sustainable development of national science competitions to compete at an international level competition , 4) Providing opportunities for students to understand the meaning of healthy competition and being competitive. The study was conducted by using descriptive and case study research. Subject were 45 junior high school students of class VII and VIII. The study design on the first stage was selection of students from the level of school, city, province, national, and international. In the national level, best students were being selected, and quarantined for several months through the National Science Olympiad (OSN) and 6 students were sent to international event. Second phase were the implementation phase of development (process) which aims to train the courage. Method of data collection include: mastery of Chemistry (daily test) and simulation. The scope of the material presented step by step from simple to difficult level. The material was equal to the high school level in Indonesia (SBC), and high school level in English. Evaluation of readiness simulation is given internally by a preceptor team and competent and experienced independent team. Simulation phase was performed three times. Data processing method was done by the Olympic preceptor team, consist of teachers in the early stage, while the final stage is given by an independent team. As final result, the team received 15 medals consist of : 3 gold medals, 5 silver medals, 4 bronze medals, and examination test group received 3 bronze medals (3rd champion).
\end{abstract}

Keywords: Pattern Formation, IJSO, Science,Chemistry, Physics, Biology

\begin{abstract}
Abstrak
Tujuan International Juniors Science Olympiad (IJSO) adalah : 1) Meningkatkan minat para siswa terhadap mata pelajaran sains (Fisika, Kimia dan Biologi) dan Matematika sejak mereka duduk di tingkat SMP, 2) Memberikan Motivasi kepada para siswa agar mereka semakin giat belajar, 3) Sebagai wahana pembinaan berkelanjutan dari lomba sains nasional untuk berkompetisi pada lomba tingkat internasional, 4) Memberikan kesempatan pada siswa untuk lebih memahami arti persaingan yang sehat dan kompetitif. Penelitian dilakukan dengan menggunakan metode deskriptif dan jenis penelitian studi kasus. Subjek penelitian sebanyak 45 orang siswa SMP kelas VII dan VIII . Rancangan penelitian pada tahap awal berupa seleksi siswa yang meliputi: Sekolah, ketingkat kabupaten/kota, propinsi, nasional, dan internasional, Tingkat nasional siswa diseleksi yang terbaik, dan Pembinaan siswa dikarantina selama beberapa bulan melalui seleksi jalur Olimpiade Sains Nasional (OSN) dari mulai tingkat sekolah, kabupaten/kota, propinsi hingga tingkat nasional untuk keajang internasional sebanyak 6 siswa. Pada tahap kedua tahap pelaksanaan pembinaan (proses) yang bertujuan untuk melatih keberanian Metode pengumpulan data yang terdiri dari: penguasaan Materi Kimia (tes harian) dan tes simulasi. Lingkup materi disampaikan secara bertahap dari konsep sederhana sampai ke tingkat yang sulit, materi setingkat SMA di Indonesia (KTSP), dan tingkat SMA di Inggris A level. Evaluasi kesiapan simulasi diberikan secara internal oleh tim pembina dan tim independen yang kompeten dan berpengalaman. Tahap simulasi dilakukan tiga kali. Metode pengolahan data dilakukan oleh tim pembina olimpiade yang terdiri dari tim pengajar pada di tahap awal dan tim independen di tahap akhir. Hasil akhir diperoleh 15 medali yang terdiri dari: 3 Emas, 5 Perak, 4 Perunggu.
\end{abstract}

Kata Kunci: pola pembinaan, IJSO, IPA, Kimia, Fisika, Biologi

\section{PENDAHULUAN}

Nucleus dari sebuah negara adalah sumber daya manusia (SDM) yang berkualitas, dengan kata lain SDM merupakan suatu asset terbesar dari suatu negara. untuk mencapai hal tersebut diperlukan suatu proses pendidikan dan pelatihan yang terus menerus, peningkatan persentase penduduk yang memiliki tingkat pendidikan berkualitas harus diupayakan dalam mencapai critical mass yang dibutuhkan untuk pembangunan nasional yang diharapkan. 
Sehubungan itu, Direktorat Pembinaan Sekolah Menengah Pertama, Direktorat Jenderal Manajemen Pendidikan Dasar dan Menengah, Departemen Pendidikan Nasional telah menyusun Rencana Strategis (Renstra) yang didalamnya berintikan penuntasan wajib belajar (Wajar) Pendidikan Dasar. Tahun yang disusun dalam Renstra merupakan salah satu langkah strategis untuk mencapai critical mass. Oleh karena itu, Kementerian Pendidikan Nasional Memprakarsai dan menjadi peserta International Junior Science Olympiad (IJSO) sejak tahun 2004. Gagasan dan prakarsa tersebut didasari atas kesadaran Bangsa Indonesia terhadap arti penting sains bagi kehidupan umat manusia, serta sains dan teknologi merupakan bagian yang melekat dengan indentitas kemajuan suatu bangsa. Menyadari hal tersebut, maka minat para siswa perlu dimotivasi agar menyenangi dan memiliki semangat untuk mempelajari sains.

Sesuai visi Pendidikan Ilmu Pengetahuan Alam (IPA) di tingkat SMP diharapkan dapat mempersiapkan siswa yang melek sains dan teknologi. Kesadaran siswa akan sains dan teknologi akan memahami dirinya dan lingkungan sekitar melalui pengembangan keterampilan proses, sikap ilmiah, dan keterampilan berpikir. Siswa yang menguasai, konsep sains yang essensial dengan tuntutan kurikulum KTSP, maka mampu mengamati perubahan alam, bersikap ilmiah, memahami proses pembentukan ilmu melalui pengamatan. Siswa juga mampu, memanfaatkan sains untuk menjelaskan prinsip sains pada produk teknologi disekitarnya. Siswa mampu merancang produk teknologi sederhana dengan menerapkan prinsip sains dan mampu mengelola lingkungan dan memanfaatkan sumber daya alam secara bijaksana.

Fakta di lapangan bahwa mutu pendidikan sains masih rendah, selama dua puluh tahun terakhir di tingkat Nasional menunjukkan rata-rata nilai Ujian Nasional di SMP pada mata pelajaran Matematika dan IPA masih tidak mencapai angka 6 dari 10. Menurut informasi dari Trend in Mathematics and Science Study (TIMSS), kualitas pendidikan di Indonesia khususnya pendidikan dasar dan menengah kurang memuaskan, dikarenakan kemampuan IPA siswa berada di urutan 32 dari 38 negara. Adanya kesenjangan antara hasil yang diharapkan dengan fakta di lapangan, perlu adanya usaha ke arah peningkatan hasil belajar siswa. Untuk menjembataninya, maka perlunya siswa diikut sertakan dalam olimpiade sains tingkat Internasional sebagai bagian dari motivasi.
Tujuan International Juniors Science Olympiad (IJSO) adalah: 1) meningkatkan minat para siswa terhadap mata pelajaran sains (Fisika, Kimia dan Biologi) sejak duduk di tingkat SMP; 2) memberikan motivasi kepada para siswa agar semakin giat belajar; 3) wahana pembinaan berkelanjutan dari lomba sains nasional untuk berkompetisi pada lomba tingkat internasional; 4) memberikan kesempatan pada siswa untuk lebih memahami arti persaingan yang sehat dan kompetitif.

Direktorat Pembinaan SMP telah merintis kegiatan lomba international bidang sains sejak tahun 2004 yang diberi nama International Juniors Science Olympiad (IJSO). Sekilas kami gambarkan pelaksanaan International Juniors Science Olympiad (IJSO) sebagai berikut: 1) IJSO ke-1 dilaksanakan di Jakarta pada tanggal 5-14 Desember 2004 dengan berhasil memperoleh 5 medali emas dan 4 medali perak dan Indonesia berprestasi sebagai juara umum dan mendapatkan absolute winner; 2) IJSO ke-2 dilaksanakan di Yogyakarta pada tanggal 4-13 Desember 2005 yang diikuti oleh 30 negara, Tim Indonesia berhasil memperoleh 6 medali emas, 4 medali perak dan 2 Medali Perunggu, serta Tim Indonesia berprestasi sebagai juara umum dan mendapatkan absolute winner; 3) IJSO ke-3 dilaksanakan di Sao Paolo, Brazil pada tanggal 3-12 Desember 2006 yang diikuti oleh 36 negara tim Indonesia berhasil memperoleh 2 medali emas, 3 medali perak dan 1 medali perunggu; 4) IJSO ke-4 dilaksanakan di Taipe Taiwan pada tanggal 2-11 Desember 2007 Tim Indonesia berhasil memperoleh 1 medali emas, 2 medali perak dan 3 medali Perunggu; 5) IJSO ke5 dilaksanakan di Gyeongnam Korea Selatan pada tanggal 7-16 Desember 2008 Tim Indonesia berhasil memperoleh 4 medali emas, 4 medali perak dan 1 Medali Perunggu; 6) IJSO ke-6 dilaksanakan di Yogyakarta pada tanggal 2-10 Desember 2009 Tim Indonesia berhasil memperoleh 5 medali perak dan 1 Medali Perunggu dan ke-7 tahun 2010 dilaksanakan pada bulan Desember 2010 di Nigeria. Calon peserta IJSO yang mewakili Indonesia harus dipersiapkan dengan matang, maka diperlukan suatu mekanisme seleksi untuk merekrut siswa SMP atau MTs terbaik dari wilayah Indonesia.

\section{METODE PENELITIAN}

Penelitian dilakukan dengan menggunakan metode deskriptif dan jenis penelitian studi kasus. Subjek penelitian sebanyak 45 orang siswa SMP kelas VII dan VIII. Rancangan penelitian pada 
tahap awal berupa seleksi siswa yang meliputi: Sekolah, ke tingkat kabupaten atau kota, propinsi, nasional, dan internasional, tingkat nasional siswa diseleksi yang terbaik. Setelah seleksi dilakukan pembinaan. Siswa dikarantina selama beberapa bulan melalui seleksi jalur Olimpiade Sains Nasional (OSN) dari mulai tingkat sekolah, kabupaten atau kota, propinsi hingga tingkat nasional untuk keajang internasional sebanyak 6 siswa.

Metode pengumpulan data yang terdiri dari: penguasaan Materi Kimia (tes harian) dan tes simulasi terdiri dari simulasi pertama terdiri dari: 1 , 2, dan 3, simulasi kedua (internal), simulasi ketiga (internal), dan simulasi keempat indepeden. Lingkup materi disampaikan secara bertahap dari konsep sederhana sampai ke tingkat yang sulit, materi setingkat SMA di Indonesia (KTSP), setara setingkat SMA di Inggris pada level A. Evaluasi kesiapan simulasi diberikan secara internal oleh tim pembina dan tim independen yang kompeten dan berpengalaman. Metode pengolahan data dilakukan oleh team pembina olimpiade sebagai pengajar di tahap awal sedangkan di tahap akhir diberikan oleh tim independen.

\section{HASIL DAN PEMBAHASAN}

Hasil test kompetensi dari serangkai simulasi yang dilakukan, maka dapat diketahui kemampuan siswa terhadap pemahaman materi IJSO yang telah dibina, hasil tes kompetensi dari simulasi baik simulasi pertama yang terdiri dari tiga tahap, simulasi kedua dan ketiga secara internal, serta simulasi keempat secara independen dipaparkan dalam bentuk grafik.

Berdasarkan tes kompetisi menunjukkan bahwa, kemampuan pemahaman konsep-konsep dasar untuk setiap bidang bervariasi (Gambar 1). Pada bidang Fisika rentang nilai tes kompetisi dengan nilai maksimal 10 (sepuluh) berada pada kisaran 3 sampai 8,5 dengan rerata 6,04. Pada bidang Biologi berada pada kisaran 6,5 sampai dengan 10 dengan rerata 8,54. Pada bidang Kimia pada kisaran 4 sampai dengan 6,25 dengan rerata 5,58. Keseluruhan nilai tes kompetisi dengan nilai maksimal 30 berada pada kisaran 14 sampai dengan 24,25 dengan rerata 20,17. Pencapaian berdasarkan hasil tes kompetisi menunjukkan berada pada kisaran 46,67\% sampai dengan 80,83\% dan mempunyai rerata pencapaian $60,69 \%$. Nilai terbaik dan pencapaian terbaik diperoleh Mikael Harseno.
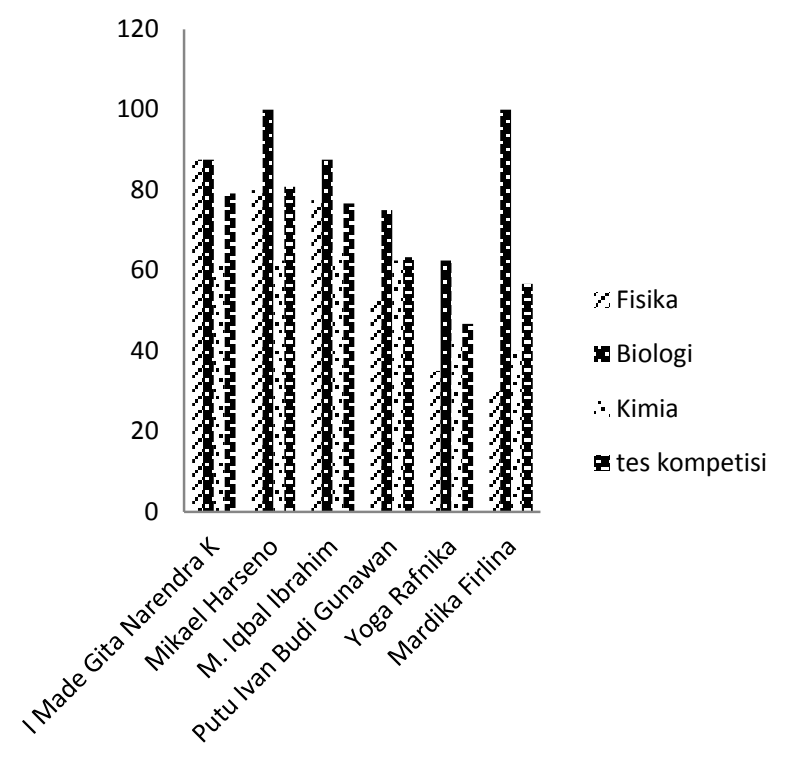

Gambar 1. Tes kompetisi

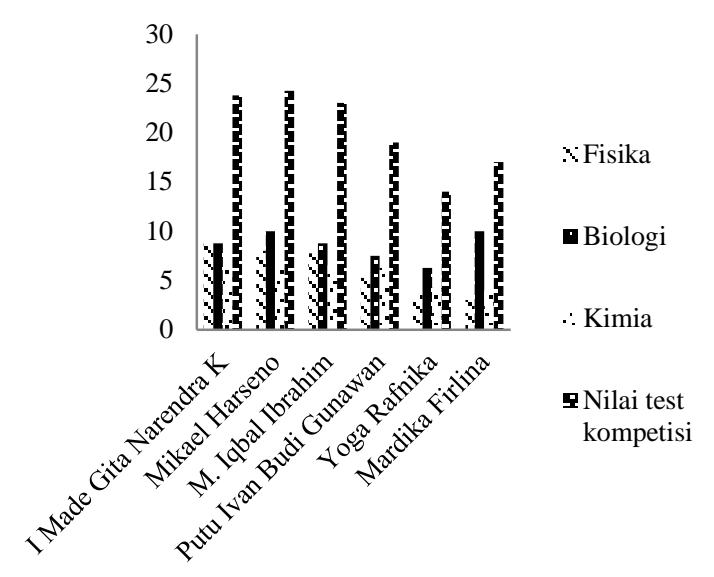

Gambar 2. Grafik Pencapaian

Gambar 2 adalah hasil tes dengan tipe soal berupa konsep bentuk gambar, diagram, pernyataan, tabel, dan data eksperimen. Hasil tes kompetesi tersebut belum maksimal. jika dibandingkan dari ketiga macam tes. Bentuk tes kompetisi lebih tinggi dibandingkan teori dan eksperimen. Hal ini disebabkan bentuk soal yang diberikan berupa penalaran. Hal ini menunjukkan pada umumnya siswa belum dapat menalar dengan baik. Selain itu siswa belum terbiasa mengerjakan soal secara komprehensip (beberapa materi pokok). Siswa terbiasa dengan mengerjakan soal satu pokok materi saja. Berdasarkan hasil tersebut dibuat rencana tindak lanjut dalam pembinaan berupa pemberian soal dalam bentuk penalaran dan diberikan dalam tiap minggu. 


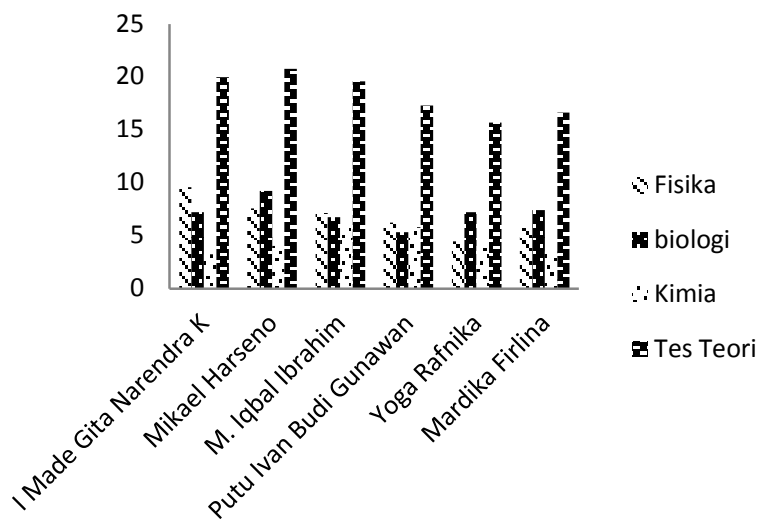

Gambar 3. Tes Teori

Hasil serangkaian simulasi didapatkan informasi mengenai kemampuan siswa terhadap pemahaman materi pembinaan IJSO. Hasil tes kompetisi simulasi IJSO pertama berupa tes teori menunjukkan bahwa kemampuan elaborasi penggunaan konsep untuk memecahkan permasalahan sains untuk setiap bidang bervariasi. Pada bidang Fisika rentang nilai tes teori dengan nilai maksimal 10 (sepuluh) berada pada kisaran 4,45 sampai 9,55 dengan rerata 6,76. Pada bidang Biologi berada pada kisaran 5,3 sampai dengan 9,2 dengan rerata 7,17. Pada bidang Kimia pada kisaran 3,2 sampai dengan 5,75 dengan rerata 4,37, untuk keseluruhan nilai tes kompetisi dengan nilai maksimal 30 berada pada kisaran 15,6 sampai dengan 20,75 dengan rerata 18,29 . Nilai terbaik diperoleh satu orang yang sama pada saat tes kompetisi sebelumnya yaitu Mikael Harseno (Gambar 3).

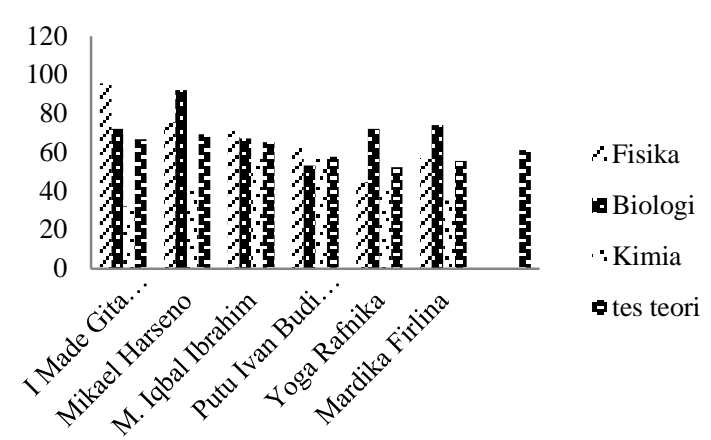

\section{Gambar 4. Persentase Pencapaian}

Persentase pencapaian dari tes teori sains berada pada kisaran $52,17 \%$ sampai dengan $69,17 \%$ dan rerata pencapaian $60,67 \%$. Pencapaian terbaik tetap diperoleh satu siswa yang mengungguli tes sebelumnya yaitu Mikael Harseno (Gambar 4). Bentuk soal berupa wacana hasilnya belum mencapai maksimum, dikarenakan pada umumnya siswa belum dapat mengaplikasikan antara konteks wacana dengan pemahaman konsep yang dikuasai masing-masing siswa.

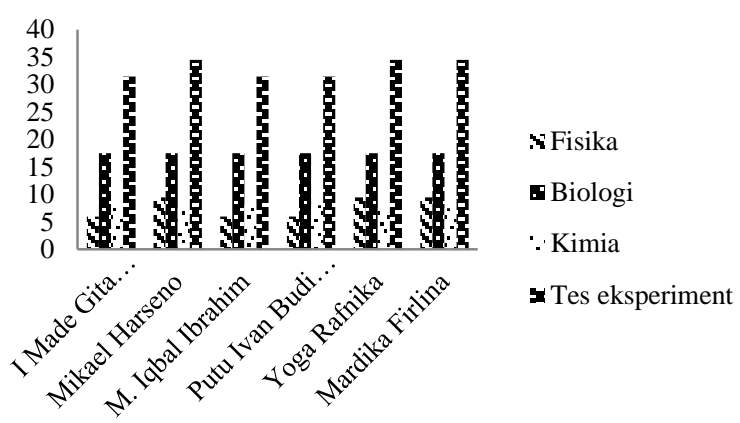

\section{Gambar 5. Hasil Tes Eksperimen}

Tes Eksperimen bentuk soal pertanyaan yang mengacu pada data eksperimen. Hasilnya masih belum mencapai maksimal (100\%). Hal ini disebabkan pada umumnya siswa belum maksimal dalam menuliskan persamaan reaksi, dan menuliskan bahasa simbol. Padahal dalam menyelesaikan perhitungan kimia kedua komponen tersebut sangatlah penting. Grafiknya dapat ditunjukkan pada Gambar 5.

Berdasarkan Gambar 5 hasil eksperimen di atas dapat menunjukkan bahwa kemampuan untuk memecahkan permasalahan sains melalui kegiatan praktikum untuk setiap bidang bervariasi, seperti untuk bidang Fisika rentang nilai tes eksperimen dengan nilai maksimal 12 (sepuluh) berada pada kisaran 6 sampai 9,5 dengan rerata 7,75, untuk bidang Biologi memperoleh nilai 17,5 dari nilai maksimal 18 dan untuk bidang Kimia pada kisaran 7,5 sampai dengan 8 dengan rerata 7,75 dari nilai maksimal 10. Untuk keseluruhan nilai tes eksperimen dengan nilai maksimal 40 berada pada kisaran 31,5 sampai dengan 34,5 dengan rerata 33.

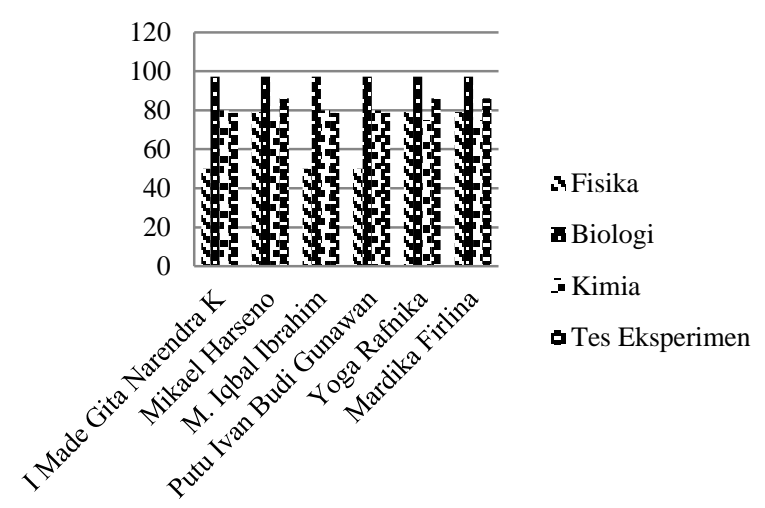

Gambar 6. Grafik Pencapaian

Berdasarkan Gambar 6 tes pencapaian berdasarkan hasil tes teori menunjukkan berada 
pada kisaran $78,25 \%$ sampai dengan $86,25 \%$ dan mempunyai rerata pencapaian $82,5 \%$. Pencapaian hasil rekapitulasi pada hasil simulasi IJSO pertama, menjelaskan pencapaian hasil pembelajaran berdasarkan evaluasi simulasi IJSO yang terdiri dari 3 jenis tes yaitu tes kompetisi, tes teori dan tes eksperimen. Berdasarkan pencapaian tersebut dapat ditunjukan bahwa pencapaian berkisar antara 64,15 sampai dengan 79,5 dari nilai maksimal 100 dengan rerata pencapaian 71,46. Sehingga, persentase pencapaian tes teori pada kisaran 78,25\% sampai dengan $86.25 \%$ dan mempunyai rerata pencapaian $82.5 \%$.

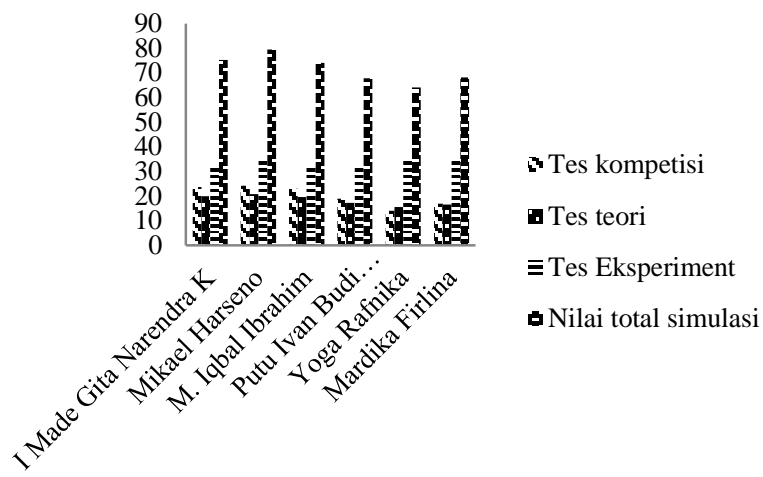

Gambar 7. Hasil Simulasi

Berdasarkan Gambar 7 hasil simulasi menunjukkan bahwa perolehan nilai bidang studi Fisika dan Biologi sudah lebih baik dari Kimia. Hal ini disebabkan masing-masing bidang studi mempunyai tingkat kesulitan yang berbeda-beda. Rencana tindak lanjut yang akan dilakukan dalam pembinaan, antara lain: siswa diminta untuk menjelaskan konsep-konsep yang dibahas dalam proses pembelajaran di kelas, sehingga siswa dapat mengkomunikasikan hasil asimilasi pemahamannya. Dengan kemampuan berkomunikasi, siswa dapat menkonstruksi sendiri pengetahuan dan teman sejawat juga terstimulus dalam perbaikan hasil konstruksi yang dimiliki masing-masing.

Hasil test simulasi I menunjukkan bahwa kemampuan siswa dalam mengkaji wacana belum optimal dengan rerata di bawah nilai 50. Hal tersebut dapat ditunjukkan bahwa kontribusi setiap bidang studi terhadap hasil simulasi secara keseluruhan tersebar (tidak merata) dengan kemampuan umum tiap bidang studi masih terfokus pada individu-individu tertentu saja. Walaupun ada sedikit pengaruh dari hasil pembinaan intensif OSN Medan.

Sebaran yang paling menonjol diantara ketiga tes (Kompetisi, Teori dan Eksperimen) tersebut adalah tes teori. Hal ini disebabkan karena kemampuan siswa dalam mengkaji wacana belum optimal, sehingga belum mampu menghubungkan antara wacana dengan teori yang telah dimiliki. Hasil dari Gambar 8 dapat dinyatakan bahwa pendekatan dalam Simulasi Pertama masih belum komprehensif. Dengan demikian perlunya, pembinaan lebih intensif dalam menganalisis masalah di wacana khususnya pada bidang studi Fisika dan Biologi. Sedangkan untuk bidang studi Kimia masih diperlukan latihan-latihan berbentuk konseptual. Untuk perbaikan simulasi berikutnya dilakukan oleh tim eksternal untuk menghindari subjektifitas pengajar (Gambar 8). Maka diperlukan simulasi oleh tim eksternal, sehingga hasil simulasinya menjadi lebih valid lagi. Analisa dan tindak lanjut deskripsi hasil simulasi (Gambar 7) dari ketiga komponen tes dapat dijelaskan pada grafik. Kontribusi bidang terhadap Hasil Simulasi pertama.

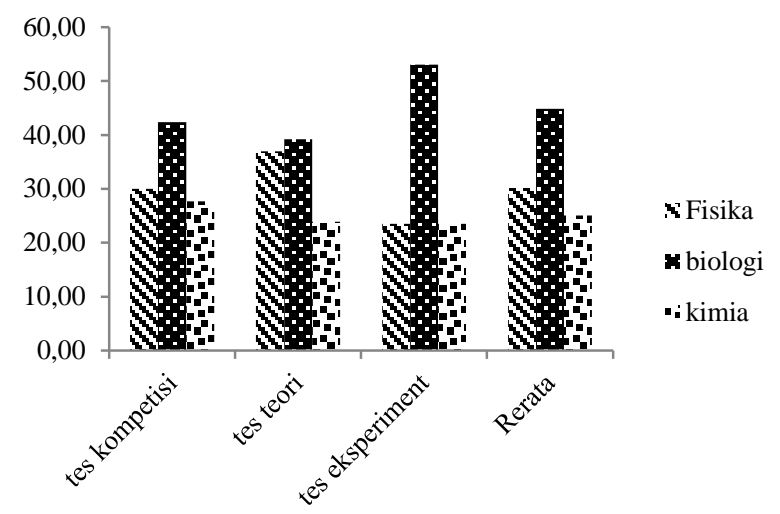

Gambar 8. Hasil Simulasi Pertama

Berdasarkan Gambar 8 hasil simulasi pertama di atas dapat ditunjukkan bahwa kontribusi setiap bidang studi terhadap hasil simulasi secara keseluruhan, hasilnya ternyata perolehannya sangat tersebar (tidak merata), ini menunjukkan bahwa kemampuan umum tiap bidang studi masih terfokus pada individu-individu tertentu saja. Ada sedikit pengaruh dari hasil pembinaan intensif OSN Medan terbukti siswa yang dipersiapkan untuk memperkuat bidang Fisika nilainya juga baik, walaupun tidak terlalu menggembirakan, demikian juga untuk bidang studi Biologi dan Kimia. Sebaran yang paling menonjol diantara ketiga tes (Kompetisi, Teori dan Eksperimen) tersebut adalah tes teori hal ini disebabkan karena kemampuan siswa dalam mengkaji wacana belum optimal, sehingga belum dapat menghubungkan antara wacana dengan teori yang telah dimiliki dan perlu diberikan penjelasan bahwa pendekatan dalam Simulasi Pertama masih belum komprehensif. Hasil 
simulasi kedua (internal) merupakan tahap evaluasi kesiapan siswa secara internal setelah uji coba OSN SMA selesai dilakukan. Uji coba tersebut dilakukan guna mengukur tingkat kemampuan siswa dalam menguasai materi setelah disampaikan $100 \%$ total materi. Hasil simulasi dapat disajikan dalam Gambar 9.

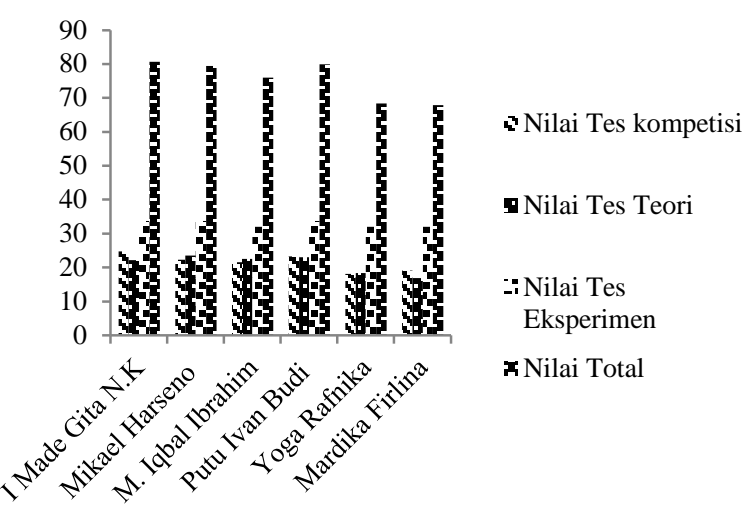

Gambar 9. Hasil Simulasi Kedua

Berdasarkan Gambar 9 hasil simulasi kedua menjelaskan pencapaian hasil pembelajaran berdasarkan evaluasi simulasi yang terdiri dari 3 jenis tes yaitu tes kompetisi, tes teori dan tes eksperimen. Berdasarkan pencapaian tersebut dapat ditunjukan bahwa pencapaian berkisar antara 67,84 sampai dengan 80,59 dari nilai maksimal 100. Hal ini menunjukkan peningkatan prestasi, walaupun tidak terlalu signifikan karena belum mencapai nilai > 85,00 sebagai target nilai minimum meraih medali emas.

Hasil simulasi ketiga (internal) merupakan tahap evaluasi kesiapan siswa akhir secara internal setelah pembinaan selesai dilakukan (Gambar 10). Simulasi ini dilakukan untuk mengukur tingkat kesiapan siswa dalam menguasai materi setelah penguatan materi pembinaan. Hasil evaluasi berikutnya dengan simulasi independen.

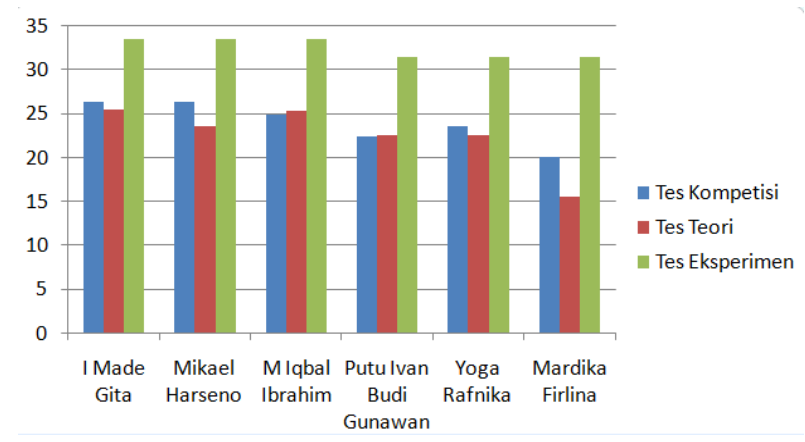

Gambar 10 Hasil Simulasi Ketiga

Berdasarkan Gambar 10 hasil simulasi ketiga menjelaskan pencapaian hasil pembelajaran berdasarkan evaluasi simulasi yang terdiri dari 3 jenis tes yaitu tes kompetisi, tes teori dan tes eksperimen. Berdasarkan pencapaian tersebut dapat ditunjukan bahwa pencapaian berkisar antara 66,80 sampai dengan 85,00 dari nilai maksimal 100 . Berdasarkan pencapaian tersebut dapat ditunjukan bahwa pencapaian berkisar antara 67,84 sampai dengan 80,59 dari nilai maksimal 100. Hal ini menunjukkan peningkatan prestasi, walaupun sudah ada salah satu siswa yang mampu mencapai nilai > 85,00 dengan target nilai minimum meraih medali emas.

Evaluasi kesiapan siswa pada simulasi keempat (independen) indikator atau kriteria kesiapan siswa yang diukur dalam proses evaluasi pembinaan, meliputi: 1) Tingkat pencapaian materi; 2) Tingkat pencapaian latihan soal (Problem Solving); 3) Kemampuan individu dan spesialisasi, 4) Kemampuan bekerjasama dalam tim. Evaluasi kesiapan siswa untuk mengikuti kompetisi olimpiade IJSO 2010 Nigeria, selain melalui mekanisme evaluasi internal (Simulasi IJSO Internal oleh Pembina IJSO) juga dilakukan melalui mekanisme Simulasi IJSO Independen (memiliki kompetensi dan pengalaman dalam pembinaan IJSO).

Simulasi IJSO Independen merupakan tahap evaluasi kesiapan sesuai dengan ruang lingkup materi sesuai Silabus 2010 dan Statuta 2009. Simulasi Independen dilakukan dalam 2 tahap evaluasi, yaitu simulasi independen pertama dan kedua. Simulasi independen pertama dilakukan tanpa melakukan evaluasi eksperimen, karena sebagian materi pembinaan praktikum simulasi independen kedua dilakukan secara lengkap dalam 3 sesi tes (Competition Examination, Theoretical Examination, dan Experimental Examination). Hasil simulasi independen yang telah dilakukan selama periode Pembinaan Tahap II ditampilkan pada Gambar 11.

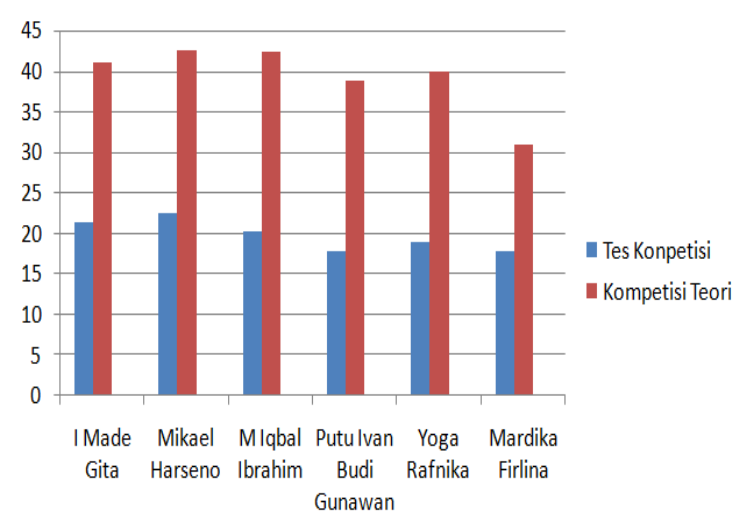

Gambar 11 Simulasi Independen Pertama 
Berdasarkan Gambar 11 simulasi independen pertama menunjukkan suatu konsistensi perkembangan prestasi siswa bila dibandingkan dengan hasil simulasi internal pertama. Hal ini dikarenakan hasil tersebut merupakan pre-test untuk materi pembinaan. Pembinaan ini berlangsung 2-3 kali pertemuan masing-masing mata pelajaran. Secara umum dapat dijelaskan pencapaian indicator atau kriteria kesiapan siswa yang diukur dalam proses evaluasi pembinaan, meliputi: Pertama, tingkat pencapaian materi: dengan ketercapaian penyampaian dan pemahaman siswa terhadap materi-materi yang terdapat pada silabus IJSO. Kedua, pada tingkat pencapaian latihan soal (Problem Solving) dimana kemampuan siswa untuk memecahkan permasalahan pada soalsoal yang mengunakan pendekatan logika. Ketiga, kemampuan individu dan spesialisasi yang ditunjukkan pada tingkat pemahaman siswa terhadap materi-materi yang sudah disampaiakan dan perbandingan kemampuan pemahaman untuk Fisika, Biologi dan Kimia, Keempat, kemampuan bekerjasama dalam tim dengan mengerjakan soalsoal praktik.

Hasil evaluasi ini menjadi patokan akhir evaluasi hasil pembelajaran (kesiapan siswa) dan digunakan sebagai masukan dalam merumuskan pembinaan akhir dengan waktu (lebih kurang 3 minggu pembinaan). Hal ini menjadi informasi dalam mencari solusi penguatan pembinaan dan merumuskan strategi tim yang akan dikirim ke Abuja, Nigeria pada tanggal 1-12 Desember 2010 dengan peserta: 33 negara.

\section{PENUTUP}

Berdasarkan tes awal pembinaan menunjukkan bahwa, kemampuan pemahaman konsep-konsep dasar untuk setiap bidang bervariasi. Dominasi nilai dan pencapaian terbaik dari ketiga mata pelajaran baik Kimia, Fisika, dan Biologi masih tidak merata. Sedangkan hasil tes kompetisi lebih tinggi dibandingkan teori dan eksperimen. Kemampuan elaborasi penggunaan konsep untuk memecahkan permasalahan sains untuk setiap bidang bervariasi, seperti bidang Fisika rentang nilai tes teori dengan nilai maksimal 10 (sepuluh) dan untuk bidang Kimia dan Biologi secara keseluruhan nilai terbaik masih didominasi oleh satu orang. Pencapaian kemampuan tes simulasi hasilnya belum mencapai maksimum, dikarenakan pada umumnya siswa belum dapat mengaplikasikan antara konteks wacana dengan pemahaman konsep yang dikuasai masing-masing siswa. Hasil Tes eksperimen hasilnya masih juga belum mencapai maksimal (100\%). Hal ini disebabkan pada umumnya siswa belum maksimal melakukan kegiatan praktikum.

Hasil simulasi dari test simulasi pertama, menunjukkan bahwa perolehan nilai bidang studi Fisika dan Biologi sudah lebih baik dari Kimia. Hal ini disebabkan masing-masing bidang studi mempunyai tingkat kesulitan yang berbeda-beda. Sedangkan secara keseluruhan, hasilnya ternyata perolehannya sangat tersebar (tidak merata). Ketidakmerataan data menunjukkan bahwa kemampuan umum tiap bidang studi masih terfokus pada individu-individu tertentu saja. Hasil simulasi kedua menjelaskan pencapaian hasil menunjukkan peningkatan prestasi, walaupun tidak terlalu signifikan karena belum mencapai nilai $>85,00$.

Hasil simulasi ketiga (internal) merupakan tahap evaluasi kesiapan siswa akhir secara internal setelah pembinaan selesai dilakukan untuk mengukur tingkat kesiapan siswa dalam menguasai materi setelah penguatan materi pembinaan. Hasil pembinaan internal ketiga menunjukkan peningkatan prestasi, walaupun sudah ada salah satu siswa yang mampu mencapai nilai $>85,00$. Minat para siswa terhadap mata pelajaran sains (Fisika, Kimia dan Biologi) selalu terjadi peningkatan walaupun setiap siswa tidak merata. Selama pembinaan siswa giat belajar dengan terbukti pada setiap simulasi masing-masing siswa perolehan nilainya signifikan.

Evaluasi kesiapan siswa pada simulasi keempat (independen) sebagai kriteria kesiapan. simulasi independen pertama menunjukkan suatu konsistensi perkembangan prestasi siswa bila dibandingkan dengan hasil Simulasi Internal Pertama. Hal ini dikarenakan hasil tersebut merupakan tingkat pemahaman siswa terhadap materi-materi yang sudah disampaiakan dan perbandingan kemampuan pemahanan untuk Fisika, Biologi dan Kimia. Profil hasil Simulasi independen (eksternal) menunjukkan peningkatan prestasi pencapaian akhir, sehingga dapat diprediksi untuk memperoleh medali. Hasil pada simulasi akhir belum mencapai nilai > 85,00 dari nilai maksimal 100. Hasil evaluasi yang dilakukan selama pembinaan dijadikan bahan untuk penentuan dan hasil simulasi independen menunjukkan peningkatan prestasi kesiapan siswa untuk mengikuti kompetisi olimpiade IJSO ketujuh 2010 Nigeria, sesuai dengan tujuannya siswa dapat menciptakan hubungan persahabatan secara Internasional dalam bidang sains sesuai dengan yang diharapkan. Hal ini terbukti berprestasi dalam 
mata pelajaran Sains di tingkat Internasional Yunior Science Olimpiad (IJSO) pelajar Sekolah Menengah Pertama (SMP) Indonesia telah mengharumkan nama bangsa pada ajang kompetisi pada IJSO di Abuja, Nigeria 1- 12 Desember 2010 yang diikuti oleh siswa-siswa dari 33 negara dengan memperoleh 15 medali yang terdiri dari: 1) juara pertama 3 Emas; 2) juara kedua 5 Perak; 3) juara ketiga 4 Perunggu; 5) juara ketiga eksperimen (satu kelompok sebanyak 3 orang) mendapat 3 Perunggu artinya siswa mampu bersaing sehat dan kompetitif.

\section{DAFTAR PUSTAKA}

Abdullah S. 2010. Modul Teori dan Tugas Mandiri Kimia. Persiapan IJSO 2010. Rexa Education Centre.

Achmad H, dkk. 2005. Program Peningkatan Sumber Daya Manusia Dalam Sains/Kimia. Bandung: Kimia ITB. Tidak dipubilkasikan..

Anshory I. 1988. Mudah Memahami Kimia SMA IB. Bandung: Armico.

Anshory I. 1988. Penuntun Pelajaran Kimia Untuk SMA Kelas II. Bandung: Ganesa Exact.

Anshory I. 2000. Acuan Pelajaran Kimia SMU Jilid 3. Jakarta: Erlangga.

Brady JE. 1999. Kimia Universitas Asas dan Struktur. Edisi Kelima jilid satu. Jakarta.

Chang R. 1998. Chemistry. Sixch Education Printed in the United State of Americe: Mc Growhill.

Cheng LW. 2002. Pass GCE O Level Science Chemistry. Shenglee, Singapore.
Campbell NA. 2006. Biology Concepts and Connections. California: The Benyamin commings Publishing.

Kemendiknas 2010. Dokumen. Jakarta: Direktorat Pembinaan SMP. Direktorat Jenderal Managemen Pendidikan Dasar dan Menengah Kemendiknas.

Eksi BY, Aydin MC. 2006. Chemical Reaction Compounds. Zambak Istambul Turkey.

Depdiknas. 2001. Kurikulum Berbasis Kompetensi Mata Pelajaran Kimia SMU. Jakarta: Pusat Kurikulum.

Depdiknas. 2001. Kurikulum Berbasis Kompetensi Mata Pelajaran Fisika SMU. Jakarta: Pusat Kurikulum.

Depdiknas. 2001. Kurikulum Berbasis Kompetensi Mata Pelajaran Biologi SMU. Jakarta: Pusat Kurikulum.

Marteen K. 2009. Fisika untuk SMA kelas X, XI, XII. Erlangga. Jakarta.

Nazli A, dkk. 2006. Hidrocarbons. Zambak Istambul Turkey.

Nazli A, dkk. 2006. Chemical Reaction Compounds. Zombak Istambul Turkey.

Yunita. 2005. Permainan Kimia jilid I . Pudak Scientific. Bandung.

Yunita. 2007. Permainan Kimia jilid II. Pudak Scientific. Bandung. 